\title{
Internet and Journalism in North Korea: Strict Media Control in the Globalization Era
}

\author{
Erdem Güven ${ }^{1}$ \\ ${ }^{1}$ Assoc. Prof, Kastamonu University Journalism Dept., Turkey
}

\begin{abstract}
.
In this research I will try to examine the structure of the online newspapers - Rodong Sinmun and Pyongyang Times - English pages which are published compatible with the official North Korean ideology, Juche. As it is well-known, all kinds of media are under the strict control of the North Korean government. Newspapers and internet are also takes their share from that control. Media is also serving as a propaganda tool of the Kim Family and the Juche ideology. North Korean online newspapers such as Rodong Sinmun and Pyongyang Times are published in English and some other foreign languages in order to propagandize the other nations about the achievements of the ideology and the country. In this research, first of all we will try to understand the main structure of the media in general under the banner of the Juche ideology. After understanding the main structure, the brief history of the press and journalism in North Korea will be given. After 1990's the collapse of the USSR and the Eastern Bloc also affected the North Korean politics by forcing to become a more isolated country in the age of internet and globalization. This research also points out how North Korean government is responding to the globalization process and how it uses the internet in the country while protecting the Juche system. Along with the literature review method, the historical descriptive model will be used in order to explain the situation.
\end{abstract}

Keywords: Juche ideology, North Korea, Media control, Newspapers in the North Korea, Internet in North Korea 


\section{THE WORLD CONFERENCE ON SOCIAL SCIENCES \& HUMANITIES}

\section{Introduction: The Structure of the North Korean Regime}

In order to understand the North Korean media structure, first of all we have to understand the countries' sui generis ideology, Juche. North Korean system is known as the suryeong (leader) system, a kind of quasi-religious or Confucian socialism. The Kim Family, or in the words of Baris Adibelli (2016), "The Kim Dynasty", have had a sacred role in the North Korean Juche system. The founder of the state Kim Il Sung was the legendary hero and a guerrilla fighter who fights for the freedom of all Koreans against the imperialist Japanese intruders and after that against the capitalist U.S. forces. Kim Il Sung also evaluated as a hermaphrodite figure (father and the mother of the state) and referred as oboi suryeong (Parent Leader) whose maternal side is praised in accordance with Confucianism (Myers, 2010). In the words of Bruce Cumming, North Korea's "neo-socialist corporatism is a mixture of socialism, corporatism, and Confucianism" (Woong Kang, 2007). Ancient myth of Dangun Wanggeom, the mythological Korean creationism legend can also be added to this mixture. According to the legend, Dangun Wanggeom is a half-god creator of the Korean nation who was born on the sacred Baekdu San (Baekdu Mountain) (Betts, 2012). North Koreans believe that they were the descendants of him and they have his pure blood. Kim Family also elevated themselves to the level of this ancestor by creating an official story that Kim Jong Il was also born on the sacred Baekdu Mountain under a rainbow (Myers, 2010). Therefore, the sui generis Juche ideology of North Korea was created and it's also known as "Socialism in Our Style" (uri sik sahoejuui). This mixture makes North Korea different from other socialist countries and prevented it to collapse while the USSR and the other Eastern Bloc countries disappear in the 1990's although it was predicted by many scholars. For some scholars such as Jin Woong Kang (2011), contemporary North Korea became a "communist state without communism". After the collapse of the USSR and other Communist states known as Eastern Bloc, North Korea became a more isolated state and society in order to protect its regime from the capitalist attacks of the U.S. and South Korea. In this situation media serves as a propaganda tool of the regime, party and the Kim family.

\section{The Status of the Media in the North Korean Juche Ideology: A General Analysis}

North Korean government used every medium as a propaganda machine since the Korean War has started. North Korean regime is using all kinds of media channel as a propaganda tool. As it was mentioned before, North Korean regime consisting of Korean nationalism, racial purity myth, Confucianism, socialism, struggle against imperialism story, and mythology. Those ideas are transferring to the society by using education (textbooks), nationalist and socialist marches, monuments, ceremonies held in the stadiums, art and more important than that by every means of media which is under the strict control of the state (Byman and Lind, 2010). 


\title{
THE WORLD CONFERENCE ON SOCIAL SCIENCES \& HUMANITIES
}

\author{
Barcelona, Spain
}

12-14 December, 2019

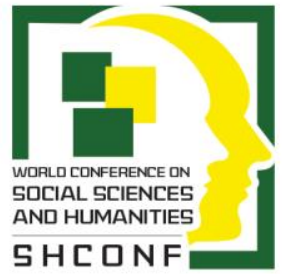

For instance, propaganda leaflets are still used by the North Korean authorities in order to effect the society. As its well-known, those posters were used by many countries, not only the totalitarian ones but also by the democratic states such as Great Britain and the U.S. in order to shape the public opinion by using the emotions that triggered such as nationalism, democracy, fear, heroism etc. According to many researchers, the propaganda posters as a type of propaganda media, helped very much to achieve victory in the 1917 Russian Revolution (Mahaney, 2002). Many states and groups (parties and organisations) still using those posters in order to tell their goals easily to the society. According to Tatiana Gabroussenko (2008), propaganda in North Korea used the theme "self-sacrifice for the party, state, leader and the Juche ideology" and has two motivations named Konan ui Haengun (March against the difficulties) and Son'gun Chongch'i (Army First).

Another important medium are the news agencies in the North Korea and in other countries. Socialist and other kinds of states have news agencies in order to control the news distributions. News agencies are especially associated with the "media imperialism" concept. North Korea's official agency is known as KCNA (Korean Central News Agency) and it is the only agency that provides the sources to the North Korean media and especially to the all newspapers of the country. The agency is also under strict state control such as the other news media. KCNA was founded at 1947 and it declares its mission as "modelling the society with the Kimilsungism and Kimjongilism ideologies and creating a new independent world". According to Kim Jong Il, the main mission of the agency is "to make the propaganda of the revolutionary ideology of Suryeong Kim Il Sung in every corner of the world" (Sim, 2017).

Radio propaganda broadcasts were and are also used and effectively keep on using by the North Korean state in accordance with the Juche system even today. Radio was used effectively by the U.S., the USSR, the UN and the other countries in the Korean War. Those "Radio Wars" also kept on between the Communist states and the imperialist Western states until 1991 when the Soviet Bloc has collapsed. The propaganda of the capitalist states became a kind of psi-op that aims:

1. Weakening the effects and the resistance of the North Korean army forces.

2. Informing the North Korean public opinion about the course of the war.

3. Recovering the morale of the South Korean army forces. (Far East Command Report, 1951).

Nowadays, North and South Korea is using the radio propaganda effectively. North Korea is trying to block the radio broadcasts from the U.S. (Radio Free Asia, VOA), Japan and South Korea by distributing special radio devices that is only compatible with the North Korean radio stations. However, some North Koreans are listening the foreign broadcasts secretly by obtaining cheap Chinese radio devices from the smugglers. 


\title{
THE WORLD CONFERENCE ON SOCIAL SCIENCES \& HUMANITIES
}

\author{
Barcelona, Spain
}

12-14 December, 2019

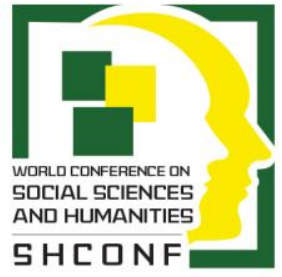

North Korea has at least fifteen radio stations which are under the control of the state. Those are, Radio Pyongyang, Yuson (Central stations); Guguk ui Sori and Pyongyang FM (Propaganda radios targeting South Korea); Kaesong, Sariwon, Haeju, Wonsan, Kangkae, Hyesan, Nampo, Sinyuiju, Hamhung, Chongjin and Pyongsung (Local radios) (Song, 2005).

Television broadcasting has a similar approach and also under strict control of the Party and the State. The main television news channel of the country is the Choson Chungang T'ellebijyon (KCTV). The channel was founded at 1 September 1953 but the broadcasting started ten years later from Pyongyang (https//www.kfausa.com/korean-central-television). Along with the KCTV there are Mansoodae TV, Gaesong TV and an educational channel. Gaesong $T V$ was founded at 1973 and its main purpose is to make propaganda broadcasting targeting South Korea.

\section{Newspapers as the Mouthpiece of The Juche Ideology: Traditional Press in North Korea}

$67^{\text {th }}$ Paragraph of the DPRK Constitution, guarantees the "freedom of expression, press, right of assembly, meeting and forming associations of all North Korean citizens" but the 63th Paragraph of the same constitution says that the "the rights and the responsibilities of every North Korean citizen depends on the collectivist principles: All for one, one for all". Therefore, the North Korean press have to protect and serve the ideology and the party (www.naenara.com.kp). This situation resembles the $125^{\text {th }}$ Paragraph of the USSR Constitution. With the effect of Marxist-Leninist ideology, the press was seen as a propaganda tool of the party. Freedom of press concept is also a kind of deceitful slogan at the bourgeois societies while the production tools are at the hands of the wealthy minority. Those people are using the press in order to shape the public opinion and deceive the people (Resis, 1977).

When we examine the North Korean press organization, we can clearly see that, the system is compatible with the other Communist countries. The most important newspaper of the country is the Rodong Sinmun newspaper, operating as the Pravda of the DPRK. The newspaper was founded at 1 November 1945 with the title Jungro. The main targets of the newspaper were and are "to narrate the revolutionary way of Juche ideology to the next generations, to be published compatible with the Juche ideology and its press theory and to follow the path of the revolutionary newspapers of Kim Il Sung era" (Sim, 2017). There were also thematic newspapers that promoted the main newspaper of the party in the other communist states. We can see the same practice in the DPRK media. For instance, the governments mouthpiece Minju Choson which was founded at 1946, targeting the officials and the workers and in order to educate them with the Kimilsungism and Kimjongilism ideologies (Sim, 2017). Another important thematic newspaper of North Korea is the Chongyon Jonwi a.k.a. Rodong Chongyon serves as the newspaper of KimilsungistKimjongilist Youth Committee. It was founded with the name Chongnyon on April 1946. There is also the newspaper of the army, Joson Inmingun which is publishing even today. 


\title{
THE WORLD CONFERENCE ON SOCIAL SCIENCES \& HUMANITIES
}

\author{
Barcelona, Spain
}

12-14 December, 2019

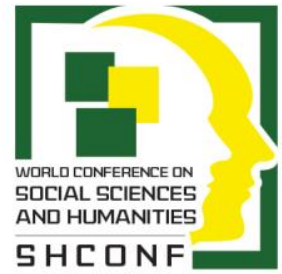

There are also local newspapers at the service of the Juche ideology such as Pyongnam, Hamnam, Hambuk, Kangwon, Hwangnam and Hwangbuk that were founded in 1945; Jakang which was founded in 1949, Kaesong that was founded in 1952 and Langkang which was founded in 1955 (Song, 2005).

\section{Did Internet Technology Changed the Press Organization and System of North Korea?: North Korean Press After the Internet}

North Korea's most important news internet sites are Rodong Sinmun, The Pyongyang Times, KCNA, and Naenara. Four of them are serving as the official mouthpiece of the Kim Dynasty and the Party. KCNA is the main source of the news and every newspaper and media gathers their news subjects from this source (Güven, 2019). The Pyongyang Times is serving as a propaganda tool for the regime outside the country. The internet sites of Naenara and Rodong Sinmun are also aiming the other countries by using different languages other than Korean.

For instance, The Pyongyang Times online has eight different sections. They are "Politics", "Economy", "Culture", "Woman", "Sports", "Reunification", "South Korea" and "International". It differs from the official newspaper Rodong Sinmun by excluding the "Supreme Leaders Activities" section and this shows that the main aim of the The Pyongyang Times is to become an international online newspaper targeting the audiences from all over the world. Therefore the "Politics" section of this online newspaper deals mostly with the Supreme Leader Kim Jong Un's activities (Güven, 2019).

As it is well-known, North Korea was a country that used the strict control methods before 1990's and they used the traditional media effectively until 1997 (Ha, 2011). North Korea was one of the nineteen countries that have had no internet connection. Along with the North Korea, those other countries were Afghanistan, Bhutan, Burma, Burundi, Congo, Gabon, Guinea Bissau, Iraq, Liberia, Libya, Mauritania, Oman, Equatorial Guinea, Rwanda, Somalia, Syria, Yemen, and Zaire in 1996 (Song, 2005). Every country had different reasons for this lack of connectivity but this media isolation in North Korea served to create and consolidate an ideology (Juche) and to build a personality cult to ensure the Kim regime's power (Güven, 2019).

After the collapse of the Communist states, the world became more globalised and the new era - global informational age - began (Castells, 2008). In this new era, and a society known as "Network Society", flow of information and connectivity became a cine qua non (Hutchins, 2004).

While South Korea is developing rapidly at the information technologies, North Korea as we can define as the black hole of the information technologies - internet technology is growing twitchily. As aforementioned, the North Korean government accepted the internet technology as a cine qua non until 1990's and started to establish an information industry technology which was strictly controlled by the regime. At the year 2000, North Korea established a kind of intranet network called Kwangmyong (Bright Light) which was and is 


\title{
THE WORLD CONFERENCE ON SOCIAL SCIENCES \& HUMANITIES
}

\author{
Barcelona, Spain
}

12-14 December, 2019

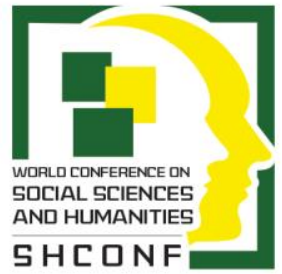

under the surveillance of the authorities (Chen, 2010). Internet was used for the scientific researches and by the party executives, scientists, engineers and partly university students.

While the internet technology is established by the state, we cannot talk about the freedom of press whether for the online newspapers and the traditional ones. The internet sites of the newspapers main aim is to praise the success of the Juche ideology and trying to propagandise the masses out of the country about that ideology.

\section{Conclusion}

North Korean authorities, especially Kim Jong Un understood the importance of the information technologies. However, internet technology also means the connection of that isolated country with the global world. So North Korean authorities established an intranet network which is known as Kwangmyong that is under the strict control of the state. Like other mass medium devices such as radio, television and newspapers of the country, internet is also serving as a propaganda tool of the state.

However, as Leonard Cohen states in one of his poems "There is a crack in everything, that's how the light gets in". Many of the young North Koreans are listening the South Korean K-Pop groups, watching American and especially South Korean movies clandestinely. Those developments are helping the North Koreans to slightly changing their opinions.

When we look at the mainstream media, its true that the North Korean authorities are using internet as a propaganda source and publishing newspapers such as Rodong Sinmun and The Pyongyang Times online. As a result, unpreventable developments in information technologies have forced the Kim Jong Un regime for a controlled and cautious change. In their internet sites, North Korea is using the same arguments such as "imperialist and villain U.S.", "lackey and puppet government of South Korea", as they are using in the traditional media.

\section{References}

[1] Adibelli, B. (2016). Kore Demokratik Halk Cumhuriyeti: Devlet, Ideoloji ve Dis Politika, Istanbul: IQ Kültür-Sanat.

[2] Betts, A.M. (2012). "North Korea: On the Path to Revolution”, M.A. Thesis, Georgetown University.

[3] Byman, D. and Lind J. (2010). "Pyongyang's Survival Strategy: Tools of Authoritarian Control in North Korea", International Security, 35 (1), pp.44-74.

[4] Castells, M. (2008). Enformasyon Toplumu: Ekonomi, Toplum ve Kültür, A $\breve{g}$ Toplumunun Yükselişi, İstanbul: Bilgi Üniversitesi Yayınları.

[5] Chen, C. et.al. (2010). "North Korea's Internet Strategy and its Political Implications", The Pacific Review, 23 (5), pp. 549-670.

[6] Gabroussenko, T. (2008). "Calls for Self-Sacrifice in North Korean Creative Writing in the Late 1900's to 2000's", The Journal of Korean Studies, 13 (1), pp.29-56. 


\section{THE WORLD CONFERENCE ON \\ SOCIAL SCIENCES \& HUMANITIES}

Barcelona, Spain

12-14 December, 2019

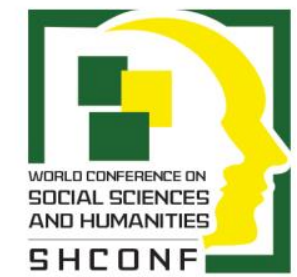

[7] Güven, E. (2019). "The Juche System and the DPR Korea Media as Official Mouthpiece of the Kim Family: Pyongyang Times Newspaper Website Analysis", Global Media Journal TR Edition, 10 (19), pp. 194-215.

[8] Kang J. W. (2011). "Political Uses of Confucianism in North Korea," The Journal of Korean Studies, 16 (1), pp. 63-87.

[9] Mahaney, D.C. (2002). "Propaganda Posters", OAH Magazine of History, 16 (3), pp. 4146.

[10] Myers, B.R. (2010). The Cleanest Race: How North Koreans See Themselves and Why It Matters, New York: Melville House Publishing.

[11] Resis, A. (1977). "Lenin on Freedom of Press", The Russian Review, 36 (3), pp.274296.

[12] Sim, O.H. (2017). Understanding Korea (Culture), Pyongyang: Foreign Languages Publishing House.

[13] Song, W. (2005). "The Changed, the Unchanged and the Implications: A Historical Examination of Mass Media in North Korea since 1945”, M.A. Thesis, University of New York at Buffalo. 